\title{
University alliances in the Europe of knowledge: Positions, agendas and practices in policy processes
}

\author{
Martina Vukasovic, CHEGG, Ghent University \\ Bjørn Stensaker, Department of Education, University of Oslo
}

\section{Introduction}

Due to the expanding competences of the EU institutions, European public sector in general and higher education and research in particular are subject to multi-level governance arrangements (Piattoni, 2010). These can also be characterized as multi-actor arrangements due to the increasing participation of non-state actors - interest groups, stakeholder organizations - that also operate across governance levels and are often organized into European associations (Elken \& Vukasovic, 2014). Involvement of non-state actors in European higher education policy-making mirrors a more general shift towards a corporate-pluralist steering approach (Gornitzka \& Maassen, 2000).

This includes the universities. In the European context, they are expected to contribute to building the European Higher Education Area (EHEA) and the European Research Area (ERA), and are affected by decisions taken at the European level. While the relationship between European policy development and national policy changes has been subject of much research, and although there are also studies focusing on how universities respond to these changes (see e.g. Elken, Gornitzka, Maassen, \& Vukasović, 2011 for a review of literature), comparatively much less is known about whether and how universities themselves impact the European policy development (but see E. Beerkens, 2008; Grande \& Peschke, 1999; Yagci, 2014).

The limited scholarly focus on the issue is inconsistent with the strong presence of various university alliances on the European stage. Apart from the European University Association, which claims to be the representative of interests of universities towards EU institutions and within the Bologna Process, there are several other alliances: e.g. European Association of Institutions in Higher Education (EURASHE, counterpart of EUA for non-universities institutions), League of European Research Universities (LERU), Network of Universities from the Capitals of Europe 
(UNICA), the Utrecht Network, Coimbra and Santander groups of universities in Europe, as well as Compostela Group which also includes universities in other parts of the world.

Many of these alliances (namely: EUA, EURASHE, LERU, UNICA, Coimbra group) have, as expressed in their mission statements, the mandate to advocate for the interest of their members towards different European actors, including EU institutions. As such, they can be considered interest groups - organizations seeking to influence public policy through lobbying, provision of expert knowledge etc. (Beyers, Eising, \& Maloney, 2008). Having in mind that interest groups as such have been studied extensively (e.g. see Beyers \& Braun, 2014; Beyers et al., 2008; Eising, 2008; Halpin, 2014; Klüver, 2012; Klüver, Braun, \& Beyers, 2015; Kohler-Koch \& Quittkat, 2011; Lowery, Poppelaars, \& Berkhout, 2008; Saurugger, 2008), and that the influence of European higher education interest groups, including university alliances, on European policy making has been identified (Klemenčič, 2012; Nokkala \& Bacevic, 2014; Yagci, 2014), it becomes even more surprising that higher education research thus far has not focused more systematically on European university alliances.

University alliances are essentially meta-organizations, i.e. organizations having not individuals but other organizations as members (Ahrne \& Brunsson, 2005, 2008), implying that their internal structures and procedures, rationale for existence and action, motivation and implications of membership, as well as their behaviour towards other organizations and individuals are different from typical organizations who have individuals as their members. Moreover, university alliances can differ considerably as to the ways they are set-up. In general, it is possible to sort them along a continuum where, on the one side, there are alliances which build their legitimacy on representativeness (with broad and open membership) and, on the other side, alliances which build their legitimacy on special characteristics (excellence, geographical location, etc.), thus being more selective as to potential membership. Along this continuum, one can identify EUA as belonging to the first category, while LERU is a university alliance belonging to the second category.

The present study aims to increase our knowledge on the role university alliances play in multi-level multi-actor governance of higher education in Europe. Specifically, the following research questions guide the analysis:

1. How does membership of European university alliances affect their position in the European policy arena?

2. What is the relationship between membership of European university alliances and their policy agendas? 
3. How does membership of European university alliances affect their practices with regards to policy formation and lobbying?

Theoretically, the article primarily builds on: (a) organizational studies, in particular the more recent insights into meta-organizations (Ahrne \& Brunsson, 2005, 2008) and (b) studies of interest groups and their role in European integration processes. Empirically, the study is based on mapping of the key characteristics of EUA and LERU, focusing, on the one hand, on diversity of their membership and on the other hand, their positions in the policy arena (i.e. status), policy agendas and their policy formation and lobbying practices, based on analysis of their statutory, strategic and policy documents.

\section{Theoretical framework}

\section{University alliances as interest groups}

Like many fashionable concepts, multi-level governance (MLG) is a multifaceted one, marking upwards, downwards as well as sideways shifts away from the sole authority of a sovereign state (Hooghe \& Marks, 2003). Recent conceptualizations also highlight that MLG is also a multi-actor phenomena, leading to identification of three distinct dimensions of the 'MLG analytical space': the centre-periphery dimension, the state-society dimension and the domestic-international dimension (Piattoni, 2010).

Activities of university alliances seeking to influence European policy making in the area of higher education and research are related to the latter two dimensions. Concerning the state-society dimension, it essentially relates to inclusion of non-state actors in decision-making, i.e. the aforementioned shift towards corporate-pluralist steering (Gornitzka \& Maassen, 2000; Jungblut \& Vukasovic, 2013). Universities and their alliances constitute such non-state actors. Concerning the domestic-international dimension, it is related to the gradual, sometimes stealth, expansion of EU competences over an increasing number of public policy issues (Pollack, 2000). In response to this, non-state actors operating in national level policy arenas tend to mobilize and organize common activities on the European level, e.g. in the form of transnational university alliances.

Essentially, the combination of shifts in governance arrangements along the two dimensions state-society and domestic-international - sets the stage for transnational university alliances to act as European interest groups. Interest groups are non-state actors which, unlike social movements, are organized, with a clear political interest and mandate to influence public policy through lobbying, provision of expert knowledge etc. (Beyers et al., 2008; Eising, 2008). A distinction can 
be made between public interest groups active on issues of general concern and sectoral interest groups active on issues of immediate concern for a more narrowly defined group (Binderkrantz, 2009). University alliances are sectoral interest groups.

From the point of view of policy-makers at the European and national level interest groups are important because they can potentially provide (or withhold) valuable policy resources, such as information, expertise and political support (Braun, 2012). Their involvement is expected to increase the legitimacy of European policy-making (Saurugger, 2008), ${ }^{1}$ provided that they faithfully represent their constituents. When it comes to higher education and research policy-making on the European level, the lack of involvement of academic staff in decision-making was identified as an indication of dubious legitimacy of the Bologna Process in its early days (Neave \& Maassen, 2007). Subsequent opening up of the Bologna governance arrangements for non-state actors seems to have been done in order to boost the legitimacy of the process as such (Elken \& Vukasovic, 2014).

The literature distinguishes between 'insider' and 'outsider' interest groups, both in relation to their position in the policy arena and in relation to the practice they adopt for influencing policymakers (Eising, 2008). 'Insiders' have a privileged position and are given the possibility to engage with the policy-makers directly. 'Outsiders' are not part of the relevant policy arena and opt for public pressure and the use of media to influence policy-makers indirectly. The position denotes how relevant policy-makers perceive an interest group and how and to what extent they are willing to involve it in the process of policy-making. The lobbying practice concerns the interest group's choice of means for influencing the policy-makers - direct lobbying or indirect public pressure and this can vary over time or across policy issues (Beyers et al., 2008). Maloney, Jordan, and McLaughlin (1994) warn that the 'insider'/'outsider' distinction with regards to position should not be conflated with the 'insider'/'outsider' distinction concerning lobbying practice, i.e. an 'insider' in the policy arena can still accept an 'outsider' strategy. The choice of lobbying practice is particularly complicated for the interest groups involved in European policy-making, given the variety of actors - European Parliament, European Commission, Council of Ministers etc. - and the complex relationships between them.

Interest groups are characterized by the tension between the logic of influence - focusing externally on policy-makers, and the logic of membership - focusing internally on the needs and preferences of members (Schmitter \& Streeck, 1999). Existence of such tension highlights the importance of membership of interest groups. First, as argued by Binderkrantz (2009), sectoral interest groups (such as the university alliances) have to rely on their membership to build their own

\footnotetext{
${ }^{1}$ For the debate concerning the extent of the European democratic deficit see e.g. Follesdal and Hix (2006) response to Majone (1999) and Moravcsik (2002), as well as the special issue of JEPP on demoi-cracy (2014, vol. 22, n. 1).
} 
legitimacy and representativeness. Secondly, the tension between the two logics, as well as the precariousness of their position vis-à-vis the policy makers, means that interest groups are continuously experiencing 'mortality anxiety' (Gray \& Lowery, 1997). While such anxiety can be due to environmental factors - changes in the policy arena and competition from other groups - it can also be linked to internal characteristics, in particular their identity (Halpin \& Thomas, 2012). For this, it is important to recognize that university alliances operating on the European level are effectively meta-organizations - organizations with other organizations as members (Ahrne \& Brunsson, 2008).

\section{Expectations regarding university alliances as meta-organizations}

Apart from pooling resources and forming interest groups in order to exert more influence over the policy makers, one of the main rationales for organizations (in this case universities) to join into meta-organizations (in this case university alliances) is the creation of new and/or reinforcement of established organizational categories. For meta-organizations, one can identify a relationship between members' organizational identities and positions in their policy arenas and the identity and position of their meta-organization in the European policy arena. Such distinction does not exist in organizations whose members are individuals (Ahrne \& Brunsson, 2008). For example, for a European university alliance to recognize itself (identity) and to be recognized (position) as a representative of a particular group, the bulk of its members need to be recognized as representatives of that particular group in their own policy contexts.

First, this has potential implications for the position of university alliances in the European policy arena. In general, representativity is established by having as many members as possible (Ahrne \& Brunsson, 2008, p. 86). High number of members is regarded as a way to increase public legitimacy and the likelihood of being recognized as a representative organization, and therefore being granted access into the relevant policy arenas. In the case of organizations seeking to represent the interest of their constituencies on the European level, they should have a sufficient amount of members from a sufficient number of European countries. In such organizations, membership tends to be relatively open - e.g. to all universities from European countries, regardless of their type (public or private), status and prestige.

However, legitimacy can also be based on status and reputation (Meyer \& Rowan, 1977), and some meta-organizations are also formed accordingly, e.g. by selecting members based on the social status and the reputation of the individual organizations. In the case of the knowledge domain, where status and prestige are important currencies, universities that perform well in 
rankings - a current proxy for status - are also likely to have more weight in their national and European policy arenas, in particular given the policy focus on excellence and competitiveness based on knowledge (Erkkila, 2014). In essence, both types of university alliances - one based on heterogeneous and the other based on homogeneous membership - can be expected to have 'insider' positions in the European policy arena, though relying on different forms of legitimacy sheer numbers as opposed to high status. By extension, both types of university alliances could also be expected to have primarily 'insider' lobbying practices, engaging with the policy-makers directly.

Differences can also be expected to emerge concerning policy agendas and policy formation practices. Meta-organizations with a broader membership base reflect the multitude of potential interests of their members, leading to a comprehensive policy agenda that covers multiple policy issues in one policy domain (Beyers, 2008). At the same time, such broad interests among the members may also be difficult to articulate in distinct ways resulting in ambiguity of policy positions (Ahrne \& Brunsson, 2005, p. 440; March, Olsen, \& Christensen, 1979; Zahariadis, 2003). In turn, metaorganizations with a more selective membership could be expected to have a policy agenda focused on a handful of policy issues with a more coherent set of policy positions.

Moreover, membership profile and not least their numbers may even affect the specific policy practices employed by metaorganizations. For metaorganizations with a wide and heterogeneous membership (heterogeneous university alliances), internal hierarchy and internal coordination can be expected to be quite weak (Ahrne \& Brunsson, 2005, p. 441). Under such circumstances, one can expect that the distinction between internal policy formation and lobbying is more easily blurred given that specific preferences and positions are negotiated more in the open. Contrary to this, metaorganizations with fewer and more homogeneous members (homogeneous university alliances) would be expected to be able to devote time and resources to 'internal' consolidation of policies before particular positions are presented towards the public.

\section{Research design}

Nine university alliances are operating in Europe (Table 1). Two university alliances - EUA and LERU - have been selected as cases for comparison. In the context of this study they both are (1) meta-organizations - comprising other organizations, (2) interest-groups - having an explicit mandate to represent their members towards European level decision-makers, (3) with a European focus (unlike e.g. the Compostela group). 
(Table 1 around here)

The key distinction in the context of this study between EUA and LERU is their membership. EUA has a broad and comprehensive membership, comprising universities and their national umbrella organizations (e.g. rectors' conferences) from almost all European countries, claiming to be "the largest and most comprehensive organisation representing universities in Europe". ${ }^{2}$ LERU has a very narrow membership, comprising "leading research-intensive universities that share the values of high-quality teaching within an environment of internationally competitive research", from ten countries situated primarily in the West and North of Europe. More than $3 / 4$ of LERU members are amongst the top 100 universities (ARWU 2014 results) and none are ranked lower than top 200. EUA's organizational headquarters are based in Brussels (with a subsidiary office in Geneva), with a secretariat comprising more than 40 people. LERU's office includes six employees and is based at one of the oldest universities in Europe (and LERU founding institution) - KU Leuven.

The empirical basis consists of official policy positions of these organizations (as presented on their websites), organizational mission and value statements, statutes and similar internal procedural documents, work programmes, activity reports as well as secondary sources. Table 2 presents which sources of data are utilized for which of the key four concepts - membership, position, policy agendas and policy formation and lobbying practices.

(Table 2 around here)

\section{Results}

\section{Position in the policy arena}

\section{European University Association}

EUA is recognized as an 'insider'; it has an official consultative status in the Bologna Follow Up Group and it is called upon to comment on specific EU proposals. Moreover, it receives a part of its operational funding from the EU, not only through projects but also through administrative / institutional support (Elken \& Vukasovic, 2014; Nokkala \& Bacevic, 2014). As such, it is definitely an 'insider' in the policy arena, and has been one since the early days of European initiatives in the

\footnotetext{
${ }^{2}$ http://www.eua.be/About.aspx (page accessed 2 January 2017).

${ }^{3}$ http://www.leru.org/index.php/public/about-leru/mission/ (page accessed 2 January 2017).
} 
area of higher education and research, either as EUA or as one of its predecessor organizations Association of European Universities (CRE) and the Confederation of EU Rectors' Conferences (Nyborg, 2014). Being recognized as an 'insider' implies that EUA is considered to have the legitimacy as well as the capacity to represent its constituents. The sheer size of membership of EUA also allows for some independence from the EU with regards to resources. This in turn allows for a large secretariat (in Brussels) in which a number of professionals specialize on various issues, and enable EUA to take an active role in a number of policy processes. As indicated earlier, the EUA stresses its representativity by highlighting the size and breadth of its membership as well as the transparency and effectiveness of its internal procedures.

\section{League of European Research Universities}

While in its early days LERU had formally the position of an 'outsider', it is now shifting towards having an 'insider' position. In 2012 it was recognized as a relevant partner by the European Commission recently, as expressed in their joint memorandum of understanding. This move towards being recognized as an 'insider' is not linked to a widespread formal and explicit recognition of LERU, but is rather related to nurturing special relationship with the key player - the European Commission, and to informal contacts with a handful of well targeted actors. The elite character of these connections thus mirrors the elite character of the organization and indicates that legitimacy in European higher education policy coordination is not only related to 'size and diversity' (as is the EUA case) but also to 'status and prestige' (as is the case for LERU).

\section{Policy agendas}

\section{European University Association}

Since its foundation, EUA has adopted more than 50 individual policy positions. Almost 20 of those are more generic policy statements adopted bi-annually at EUA's main decision-making events conventions. The others are positions addressing EU institutions or responding to specific EU initiatives.

In general, EUA's policy agenda is primarily focused on: (1) the rationale for and approaches to European coordination in higher education and research (including the Bologna Process, but also EU initiatives such as the ERC and the EIT), (2) organization, purpose and funding of research (including doctoral education), (3) quality of higher education and assurance thereof, (4) role and purpose of higher education and (5) the social dimension of higher education (including issues related to equity). Other topics, such as degree structure, learning outcomes, qualifications, 
governance and decision-making are also addressed but not as frequently as the five issues listed above. Focus on specific topics in some cases reflects the dynamic of EU institutions, e.g. LLL is most prominent in 2008 around the time of adoption of the EQF, while in others it is reflecting the EUA's project activities, e.g. the strong focus on quality can be linked to numerous projects the EUA has had on quality and quality culture.

The EUA's agenda is overall quite comprehensive, including all issues addressed by European stakeholder organizations. The main policy documents are the bi-annual declarations ${ }^{4}$ which are in most cases developed also as messages to the Bologna Ministerial summits. These cover the full range of Bologna action-lines as well as highlight some issues of specific concern for EUA (e.g. financing, dissemination of research and open access etc.). In addition, the EUA also has positions concerning issues beyond higher education and research, such as public service principles for EU civil servants, as well as issues in which HE serves as a policy solution (e.g. energy policy) or issues which might affect HE (e.g. TTIP negotiations).

EUA's policy positions are rather elaborated and relatively specific. E.g. the Antwerp declaration (adopted in April 2015), is organized into three parts. The first one targets "policy makers, political leaders and decision makers at all levels - regional, national, European" and identifies stable funding as one of the priority areas. Specific positions in this respect concern arguing against cuts in Horizon 2020 funding in favour of the newly established European Fund For Strategic Investment (EFSI) as well as advocating for "minimising discrepancies in the EU 28", in particular between North/West and South/East. The second one describes a "long-term strategic agenda for universities", highlighting diversity, doctoral training and research, international collaboration, cooperation with the industry etc. The third part defines "preconditions for success", stressing the importance of academic freedom and autonomy and re-iterating the need for financial sustainability (all quotes from p.1 of document). Similar issues appear also in the EUA's message to the 2012 Bologna Ministerial Conference which took place in Bucharest. In this document, the EUA reflects on the implementation of Bologna action lines and what "the successful development of the EHEA in the coming years requires" (p.4 of document) and as well as what is necessary to further the "modernization of higher education systems and of individual universities" (p.6 of document). Policy documents from the early 2000s (e.g. the 2001 Salamanca Convention and the 2003 Graz Declaration) are also rather elaborated, strongly framed in relation to the Bologna Process, and rather clear with regards to specific preferences, e.g. while diversification of funding is encouraged, "higher education remains first and foremost a public responsibility... governments

\footnotetext{
${ }^{4}$ The first such declaration was adopted in Salamanca in 2001. The only exception to the bi-annual developments was in 2013 (no declaration), but the EUA did adopt a special message for the 2012 Bucharest Ministerial Summit.
} 
must empower institutions ... by providing stable legal and funding environments" (p. 8 of 2003 Graz Declaration).

In general, the EUA sees European coordination in $\mathrm{HE}$ as a positive development and often advocates for more 'European solutions', arguing that specific challenges put towards HE (e.g. ensuring quality) cannot be adequately addressed by national level policies alone. When there is opposition to European developments, it particularly concerns specific aspects of policy initiatives such as the EIT, ERC or rules for participation in cooperation programmes. Even here the opposition is seldom all-encompassing, but rather balanced with highlighting the positive aspects of specific initiatives and warning about potentially negative consequences for the universities. An example of this is how EUA approaches the topic of excellence; the need to improve quality and provide cutting-edge research is complemented by the focus on broadening access to HE, other purposes of HE (e.g. contributing to democratic citizenship) and the aforementioned "minimising of discrepancies". One of the few instances in which the EUA (interestingly, together with LERU) voiced a clear and all-encompassing opposition was related to cutting the Horizon2020 funding in favour of EFSI. ${ }^{5}$

While EUA's overarching policy documents seldom refer to specific quantitative targets, indicators or describe best practices in a lot of detail, responses to EU initiatives tend to be more specific, e.g. commenting on participation rules in FP programmes, setting up of the European Research Council, the ' $3 \%$ of GDP for research funding target' etc. The fact that these primarily reactive policy statements are more specific should not come as surprise, given that many EU initiatives contain specific targets themselves, making it easier for EUA to assess consequences for universities should these targets be attained and thus facilitating formulation of very specific preferences concerning such targets.

\section{League of European Research Universities}

Since its foundation in 2002, LERU has developed a range of policy positions through their “position papers", “advice papers", "briefing papers", and "LERU notes". These different papers expresses some differences in priorities where "position papers" are seen as high-level policy statements and the most important ones (12 such papers produced from 2005 - 2014), while "advice papers" are more reactions to pressing issues, not least deriving from the EU-system. The latter papers are more frequent in numbers, and LERU has produced 17 of these in the 2010-2014 period

http://www.leru.org/files/publications/20150123_ERA_stakeholders_joint_statement_on_the_european_fund_for_strate gic investments.pdf (page accessed 5 January 2017). 
alone. All of these policy positions are supported by the highest decision-making body within the LERU, the rector's assembly which meets twice a year.

In general, the four main issues in LERU's policy agenda since 2002 have been: (1) issues related to research and innovation (including doctoral education), (2) European coordination research, (3) the social dimension of higher education, and (4) the role and purpose of higher education. Other topics have also been addressed, but seem to be more ad-hoc in nature compared to the four issues mentioned which all seem to be quite regular topics for LERU to concentrate on. Issues within the field of education are sometimes also addressed by LERU, but educational issues are very much linked to doctoral training and can be said to be quite closely coupled with the interest in research and innovation. That being said, the prominence of the four topics does vary in the period since 2002 .

The dominance of research and innovation on the LERU policy agenda suggest that this alliance is quite focused in their interest articulation. However, in the latter years it is possible to identify a more broad policy agenda advocated by LERU, with more generic issues outside higher education being addressed. Still, a closer look at some of these issues shows that many of them are closely linked to Horizon2020. For example, the LERU declaration on active and healthy ageing in 2013, the conference on energy transitions in the $21^{\text {st }}$ century, the letters and statements concerning intellectual property rights, innovative medicine and open data protection in the latter years fit well with the seven societal challenges which are the basis for the priorities in Horizon 2020.

Furthermore, there is also a quite good match between the content of LERU's policy initiatives and the three pillars of Horizon2020: 1) excellence in ground-breaking research and innovation, 2) industrial competitiveness, and 3) societal relevance. When echoing these initiatives in their own policy statements and papers, LERU has sometimes opted for joining forces with other university alliances outside Europe. For example, in the so-called HEFEI statement launched in October 2013, signed by LERU and a number of other international alliances such as the American Association of Universities (AAU), Group of Eight in Australia, and the C9 university alliance in China, the importance of excellence is underlined, along with research integrity, and academic freedom.

The majority of the LERU policy positions are very tightly linked to Horizon2020, and the priorities of this research programme. Many of these positions are supportive, but some disagreements with the EU agenda and EU priorities do come to the fore from time to time. Examples of such disagreements in the latter years can be found when LERU warned against budget reductions in the Horizon2020, when LERU expressed its support for Switzerland when it was temporary excluded from participating in Horizon2020 in 2014, and when LERU advocated for 
the importance of humanities and social science research, and the lack of opportunities for these disciplinary areas in Horizon2020.

With respect to ambiguity of policy positions and recommendations, one can distinguish between more general policy positions advocating for university autonomy, academic freedom, the role of higher education, and the right for higher education institutions to set their own priorities. Such issues are usually addressed in quite generic ways, while reactions to EU developments are much more specific and detailed leaving little room for interpretations as to what the policy position of LERU is on these matters.

Overall, the policy agenda of the LERU is very concentrated on research and innovation issues and has been that way since the very early days of the alliance (early 2000s). While the alliance does address issues outside research and innovation, and where in the latter years it seems to prioritise expanding their global network to similar university alliances in key countries such as the US, China and the Asian region, the policy agenda is predominantly linked to the EU initiatives, and more specifically, Horizon2020.

\section{Practices of policy formation and lobbying}

\section{European University Association}

The main decision body is the Council, comprising presidents of national rectors' conferences, i.e. the collective full members of the EUA. ${ }^{6}$ It adopts, by simple majority, EUA policies and positions, which are developed by a smaller structure, the Board of 9 members, some current and some former rectors, one of them being the President of the EUA (articles 18-23 of the EUA Statutes). The Board, together with the Secretary General it appoints, is also responsible for implementation of the work programme. There is also an annual General Assembly comprising all full members (individual universities and their collective structures) and associate organizations (e.g. university alliances, including the Utrecht Network and UNICA), which elects the President and the Board and "determines the overall strategic direction" of EUA (article 16 of the EUA Statutes).

EUA organizes many events of various purposes. The main events are the aforementioned biannual conventions in which the over-arching policy positions are presented to all of the constituents and the public. Apart from this, EUA also develops and disseminates its policy

\footnotetext{
${ }^{6}$ It should be noted that in most cases the universities, which are EUA's individual full members, are associated into national rectors' conferences. Therefore, national rectors' conferences as collective full members of the EUA are expected to represent the interests of the individual full members' in the EUA's main decision making body - the Council.
} 
positions through various topical projects focusing on e.g. quality culture in higher education, learning and teaching, doctoral education, funding, internationalization etc. (more than 50 projects in total). These projects often provide the basis for EUA's policy agenda, by allowing EUA members to get acquainted with developments on the European level or from other European countries, consider different policy alternatives, and develop their own positions. This sometimes results in self-standing policy positions on an issue or it feeds into the more general policy documents. For example, the quality culture projects as well as EUA's Institutional Evaluation Programme $^{7}$ contributed to the 2004 and 2007 policy positions on quality assurance, but also to specific parts of the bi-annual declarations. ${ }^{8}$

While the organization's policies are developed by the afore-mentioned structures and through EUA's projects, EUA's presence 'in Brussels' is, according to its own website, also important in order to "provide[s] a point of contact, advice and expert public backing for the European institutions - the European Commission, Parliament and Council - which are active in the field of education and research" (emphasis added). ${ }^{9}$ This is primarily the function of a large Secretariat lead by the Secretary General and currently comprising almost 40 people, organized in topical teams focusing on both policy issues (research and innovation, governance and funding, general higher education policy, institutional development and quality) and more organizational aspects (communication, finances and accounting, project coordination). Based on consultation with their members, as well as using insights develop through the different events and projects, EUA claims to provide expertise and their constituents' input to the Commission (in particular DGs responsible for education and research), as well as the Committees and individual members of the European Parliament. These contacts are both formal - through organised public consultations including written responses to specific EU initiatives, as well as informal - through smaller bilateral meetings.

Overall, the EUA seems to have a rather elaborated and institutionalized approach to developing its own policy positions, building on its project activities and events and with a rather clear division of competences between its internal structures. It also has a significant administrative capacity to take advantage of its 'insider' position in the policy arena by articulating these positions directly towards the main EU institutions.

\footnotetext{
A specific membership service, focusing on evaluating universities' internal QA systems (http://www.eua.be/activities-services/institutional-evaluation-programme/Home.aspx, page accessed 5 January 2017). ${ }^{8}$ http://www.eua.be/policy-representation/quality-assurance/qa-policy-development (page accessed 5 January 2017).

${ }^{9}$ http://www.eua.be/eua-work-and-policy-area/EUA-in-Brussels.aspx (page accessed 7 August 2015).
} 


\section{League of European Research Universities}

The main decision body of LERU is the Rectors Assembly, comprising rectors of all member universities, that meets twice a year. In these meetings, which are hosted by various member institutions, a range of issues are addressed, and policy papers are presented and accepted. Three of the members of the Rectors' Assembly are in addition appointed to serve on the so-called Board of Directors, and one of these directors has a special appointment as a chairperson. This person presides over the rector's assembly and is the key political figure in between the meetings. The chairperson is supported by the secretary-general which currently is located at KU Leuven. Together with a small staff (additional five members), the LERU office takes care of the day-to-day running of the alliance.

In addition to the formal decision-making bodies and the key administrative staff, LERU also has a range of committees, working and expert groups. The most important one of these is the Policy Committee that acts as a review committee for the development of key position and policy papers. LERU has also set up various working groups, for example in areas such as alumni, charitable funding, e-learning, ethics, gender issues and some special disciplinary networks (often consisting of deans at member institutions). Expert groups focus on university rankings, research integrity, research data and legal issues (in relation to research projects).

When looking at the external activities of LERU, the most visible trend in the latter years is a consistent and very pro-active attempt to link up to other international and highly reputed university alliances. The development and signing of the so-called HEFEI statement (see above) is the most visible outcome of this engagement. However, LERU is also engaged in other activities such as a regular student conference and the annual LERU summer school for doctoral students.

Still, most of the external activities are very much related to EU matters in research and innovation policy. In 2012 LERU also signed a special memorandum of understanding with the European Commission in which LERU committed itself to carry out specific actions and processes that can contribute to the realization of the European Research Area (ERA). ${ }^{10}$ Although the LERU secretariat is not located in Brussels (but in 30-km-away Leuven), many LERU events are taking place there.

In the early days of LERU, statements were mainly published and advertised in a more 'passive' way, while in the latter years one can identify a much more active advocacy by LERU in making their positions noticed and maximising their potential impact. In the last couple of years, LERU has organized special dinner events for members of the European Commission, and the meetings with specific members of the Commission have recently become much more regular.

\footnotetext{
${ }^{10}$ EUA signed the same memorandum on the same day.
} 
Furthermore, special spring receptions in Brussels targeting a selected and high-impact audience, and addressing issues such as global health challenges, seem to be the current way LERU works to advocate their policy positions. Hence, the lobbying practice is quite targeted, exclusively linked to specific people and audiences.

\section{Discussion and conclusions}

As was presented above, both EUA and LERU have 'insider' positions in the policy arena, though on different grounds - EUA relies on the number of its members while LERU relies on the prestige. With regards to policy agendas, while EUA has a more comprehensive agenda than LERU, the organizations are similar with regards to how specific their policy preferences are; not very specific when it comes to the more overarching issues, and very specific when it comes to direct responses to EU initiatives. Moreover, EUA seems to have rather institutionalized practices to policy formation, while LERU developed its practices more recently. There are also differences concerning the lobbying practices; while EUA is involved with multiple policy actors on a wide range of issues in both formal and informal ways, LERU is more targeted and less formal.

These differences - (1) broad (EUA) vs. narrow (LERU) policy agenda and (2) broad and both formal and informal (EUA) vs. targeted and informal (LERU) approaches to lobbying - can be related to the membership of these two organizations and their positions on the EU policy arena. As indicated earlier, EUA is a comprehensive organization which highlights number of members and coverage of HE systems in Europe, while LERU is an elite organization which highlights the prestige and status of its members. Here, EUA and LERU only partially conform to expectations from meta-organizations literature. On the one hand, as expected, the comprehensive organization has a comprehensive policy agenda, while the selective one has a more focused agenda. On the other hand, both organizations seem to have relatively specific and coherent set of policy positions, which is not expected in the case of the comprehensive organization (EUA).

One possible explanation for the partial discrepancy from our theoretically grounded expectations is related to the position of the EUA in the policy arena. EUA has an official consultative status in the Bologna Follow Up Group and is called upon to comment on specific EU proposals. It has been an 'insider' since the early days of European initiatives in higher education and research (either as EUA or as its predecessor organizations). As such, EUA was expected to contribute to policy development and thus was required to develop policy positions on a number of issues. Ad-hoc policy formation that happens outside of the organization would jeopardize EUA's 
'insider' status. Furthermore, this 'insider' position can also have given the quite large secretariat of EUA more discretion to establish more specific policy positions.

Our approach of studying university alliances as meta-organizations has also nuanced some of the traditional expectations related to this form of inter-organizational collaboration and interest articulation. While the comprehensiveness of policy agendas of the alliances is in line with our expectations, it is more surprising that the lobbying practices are quite similar. Furthermore, while meta-organizations with large and diverse membership can be considered as 'weak' organizations with respect to their ability to develop strong policy positions (Ahrne \& Brunsson, 2008), it seems that these characteristics can be balanced by developing organizational capacity to follow up ongoing policy processes and to acquire the status as a 'insider' (EUA). It is also interesting that individually 'strong' universities find it necessary to join forces and to become 'insiders' as well. While LERU in the latter years clearly seems to opt for a 'insider' position, it is interesting that this has not restricted its behaviour as an 'outsider' when protests are launched and made public on certain policy issues. Whether this is a position that is a deliberate strategy to balance policy impact with support from its membership, or more a result of ambiguity, is a question for future research.

In the current study we have first and foremost described the formal set up and the routines and practices that can be identified in the day-to-day running of the university alliances as policy actors. While this approach certainly has its limitations, not least with respect to identifying the actual impact of the university alliances in affecting specific policy outcomes (Börzel, 2011), it is still a valuable approach as we have demonstrated the specific strategies applied by two quite different university alliances in their effort to be included in European multi-actor and multi-level policy processes.

Our findings suggest that there are many ways forward to be included in the European knowledge policy arena. The clearly formulated interest one can detect from EUA and LERU to play a role in these processes suggests that analytical perspectives that include societal and international actors are extremely relevant (Piattoni, 2010), and that corporatist models of governance (Olsen, 1988) may become more important for future studies in this area.

What our study has shown is that while organizational characteristics, in particular diversity of their membership of university alliances indeed may explain the comprehensiveness and ambiguity of their policy agendas, such characteristics should not be seen as deterministic criteria for the role university alliances may play in various policy processes. The reason for this is obvious. To choose between being a 'insider' and a 'outsider' in a given policy process is not only up to a given interest organization, it is also a matter for those actors granting such position. As such, the development of both EUA and LERU to become more 'insiders' can also be seen as a strategy by 
the European Commission as the most sustainable way to launch and promote their policy initiatives, and as a sign of the importance of actors such as EUA and LERU on the supranational policy scene. While these alliances certainly can be seen as interest organizations in a more narrow perspective, they can also take on the role as experts and/or implementers of policy (Beyers et al., 2008), and as such they possess a range of potential resources that may explain why they are attractive in the increasingly complex policy processes that are played out at European level. It is fairly well known that in the knowledge domain, the EU may sometimes 'skip' the national policy level when launching and implementing certain policy initiatives (Chou \& Gornitzka, 2014). In the area of higher education, university alliances could in the future be key actors in European level policy processes. Their transnational nature, the diverse sources of legitimacy they offer to policyprocesses, and the potential power they hold through these characteristics makes university alliances very attractive partners for European level policy-makers. As such our study may be said to provide a glimpse into the future of European policy-making in the knowledge area.

\section{References}

Author 1

Ahrne, G., \& Brunsson, N. (2005). Organizations and meta-organizations. Scandinavian Journal of Management, 21(4), 429-449.

Ahrne, G., \& Brunsson, N. (2008). Meta-organizations. Cheltenham: Edward Elgar.

Beerkens, E. (2008). The Emergence and Institutionalisation of the European Higher Education and Research Area. European Journal of Education, 43(4), 407-425. doi:10.1111/j.14653435.2008.00371.x

Beerkens, M., \& Vossensteyn, H. (2011). The Effect of the Erasmus Programme on European Higher Education: The Visible Hand of Europe. In J. Enders, H. F. de Boer, \& D. F. Westerheijden (Eds.), Reform of Higher Education in Europe (pp. 45-62). Rotterdam: SensePublishers.

Beyers, J. (2008). Policy Issues, Organisational Format and the Political Strategies of Interest Organisations. West European Politics, 31(6), 1188-1211. doi:10.1080/01402380802372654

Beyers, J., \& Braun, C. (2014). Ties that count: explaining interest group access to policymakers. Journal of Public Policy, 34(01), 93-121. doi:doi:10.1017/S0143814X13000263

Beyers, J., Eising, R., \& Maloney, W. (2008). Researching Interest Group Politics in Europe and Elsewhere: Much We Study, Little We Know? West European Politics, 31(6), 1103-1128. doi:10.1080/01402380802370443

Binderkrantz, A. S. (2009). Membership Recruitment and Internal Democracy in Interest Groups: Do Group-Membership Relations Vary Between Group Types? West European Politics, 32(3), 657-678. doi:10.1080/01402380902779162

Börzel, T. A. (2011). NETWORKS: REIFIED METAPHOR OR GOVERNANCE PANACEA? Public Administration, 89(1), 49-63. doi:10.1111/j.1467-9299.2011.01916.x

Börzel, T. A., Hofmann, T., \& Panke, D. (2012). Caving in or sitting it out? Longitudinal patterns of non-compliance in the European Union. Journal of European Public Policy, 19(4), 454471. doi:10.1080/13501763.2011.607338 
Braun, C. (2012). The Captive or the Broker? Explaining Public Agency-Interest Group Interactions. Governance, 25(2), 291-314. doi:10.1111/j.1468-0491.2012.01567.x

Chou, M.-H., \& Gornitzka, А. (Eds.). (2014). Building the knowledge economy in Europe: New constellations in European research and higher education governance. Cheltenham: Edward Elgar.

Eising, R. (2008). Interest groups in EU policy-making. Living Reviews in European Governance, 3(4). doi:10.12942/lreg-2008-4

Elken, M., Gornitzka, Å., Maassen, P., \& Vukasović, M. (2011). European integration and the transformation of higher education. Oslo: University of Oslo.

Elken, M., \& Vukasovic, M. (2014). Dynamics of voluntary policy coordination: the case of Bologna Process. In M.-H. Chou \& $\AA$. Gornitzka (Eds.), The Europe of Knowledge: Comparing Dynamics of Integration in Higher Education and Research Policies (pp. 131159). Cheltenham: Edward Elgar.

Erkkila, T. (2014). Global University Rankings, Transnational Policy Discourse and Higher Education in Europe. European Journal of Education, 49(1), 91-101. doi:10.1111/ejed.12063

Follesdal, A., \& Hix, S. (2006). Why There is a Democratic Deficit in the EU: A Response to Majone and Moravcsik. JCMS: Journal of Common Market Studies, 44(3), 533-562. doi:10.1111/j.1468-5965.2006.00650.x

Fraussen, B., Beyers, J., \& Donas, T. (2014). The Expanding Core and Varying Degrees of Insiderness: Institutionalised Interest Group Access to Advisory Councils. Political Studies, 63(3), 569-588. doi:10.1111/1467-9248.12112

Frølich, N., Huisman, J., Slipersæter, S., Stensaker, B., \& Bótas, P. C. P. (2013). A reinterpretation of institutional transformations in European higher education: strategising pluralistic organisations in multiplex environments. Higher Education, 65(1), 79-93. doi:10.1007/s10734-012-9582-8

Gornitzka, ̊., \& Maassen, P. (2000). Hybrid steering approaches with respect to European higher education. Higher Education Policy, 13(3), 267-285.

Grande, E., \& Peschke, A. (1999). Transnational cooperation and policy networks in European science policy-making. Research Policy, 28(1), 43-61. doi:http://dx.doi.org/10.1016/S00487333(98)00099-7

Gray, V., \& Lowery, D. (1997). Life in a Niche: Mortality Anxiety among Organized Interests in the American States. Political Research Quarterly, 50(1), 25-47. doi:10.2307/449027

Halpin, D. R. (2014). The Organization of Political Interest Groups: Desining Advocacy. London: Routledge.

Halpin, D. R., \& Thomas, H. F. (2012). Interest group survival: Explaining sources of mortality anxiety. $I G A, 1(2), 215-238$.

Hooghe, L., \& Marks, G. (2003). Unraveling the Central State, but How? Types of Multi-level Governance. American Political Science Review, 97(02), 233-243. doi:doi:10.1017.S0003055403000649

Jungblut, J., \& Vukasovic, M. (2013). And now for something completely different? Re-examining hybrid steering approaches in higher education. Higher Education Policy, 26(4), 447-461. doi:10.1057/hep.2013.28

Klemenčič, M. (2012). The Changing Conceptions of Student Participation in HE Governance in the EHEA. In A. Curaj, P. Scott, L. Vlasceanu, \& L. Wilson (Eds.), European Higher Education at the Crossroads: Between the Bologna Process and National Reforms (pp. 631653). Dordrecht: Springer Netherlands.

Klüver, H. (2012). Biasing Politics? Interest Group Participation in EU Policy-Making. West European Politics, 35(5), 1114-1133. doi:10.1080/01402382.2012.706413 
Klüver, H., Braun, C., \& Beyers, J. (2015). Legislative lobbying in context: towards a conceptual framework of interest group lobbying in the European Union. Journal of European Public Policy, 22(4), 447-461. doi:10.1080/13501763.2015.1008792

Kohler-Koch, B., \& Quittkat, C. (2011). What is 'civil society' and who represents it in the European Union? In U. Liebert \& H.-J. Trenz (Eds.), The New Politics of European Civil Society (pp. 19-39). London/New York: Routledge.

Lowery, D., \& Marchetti, K. (2012). You don't know Jack: Principals, agents and lobbying. Interest Groups \& Advocacy, 1(2), 139-170. doi:10.1057/iga.2012.15

Lowery, D., Poppelaars, C., \& Berkhout, J. (2008). The European Union Interest System in Comparative Perspective: A Bridge Too Far? West European Politics, 31(6), 1231-1252. doi:10.1080/01402380802372670

Maassen, P., \& Musselin, C. (2009). European Integration and the Europeanisation of Higher Education. In A. Amaral, G. Neave, C. Musselin, \& P. Maassen (Eds.), European Integration and the Governance of Higher Education and Research (Vol. 26, pp. 3-14). Dordrecht: Springer Netherlands.

Maassen, P., \& Olsen, J. P. (Eds.). (2007). University Dynamics and European integration. Dordrecht: Springer.

Majone, G. (1999). The regulatory state and its legitimacy problems. West European Politics, 22(1), 1-24. doi:10.1080/01402389908425284

Maloney, W. A., Jordan, G., \& McLaughlin, A. M. (1994). Interest Groups and Public Policy: The Insider/Outsider Model Revisited. Journal of Public Policy, 14(1), 17-38. doi: $10.2307 / 4007561$

March, J. G., Olsen, J. P., \& Christensen, S. (1979). Ambiguity and choice in organizations. Bergen: Universitetsforlaget.

Marginson, S., \& Rhoades, G. (2002). Beyond national states, markets, and systems of higher education: A glonacal agency heuristic. Higher Education, 43(3), 281-309. doi:10.1023/A:1014699605875

Meyer, J. W., Boli, J., Thomas, G. M., \& Ramirez, F. O. (1997). World society and the nation-state. American Journal of Sociology, 103(1), 144-181.

Meyer, J. W., \& Rowan, B. (1977). Institutionalized Organizations: Formal Structure as Myth and Ceremony. American Journal of Sociology, 83(2), 340-363. doi:10.2307/2778293

Moravcsik, A. (2002). Reassessing Legitimacy in the European Union. JCMS: Journal of Common Market Studies, 40(4), 603-624. doi:10.1111/1468-5965.00390

Neave, G., \& Maassen, P. (2007). The Bologna Process: An Intergovernmental Policy Perspective. In P. Maassen \& J. P. Olsen (Eds.), University Dynamics and European Integration (Vol. 19, pp. 135-153). Dordrecht: Springer Netherlands.

Nokkala, T., \& Bacevic, J. (2014). University Autonomy, Agenda Setting and the Construction of Agency: The Case of the European University Association in the European Higher Education Area. European Educational Research Journal, 13(6), 699-714. doi:10.2304/eerj.2014.13.6.699

Nyborg, P. (2014). The roots of the European University Association. Brussels: EUA.

Olsen, J. P. (1988). Administrative reform and theories of organization. In C. Campbell \& B. G. Peters (Eds.), Organizing governance, governing organizations (pp. 233-254). Pittsburgh: University of Pittsburgh Press.

Piattoni, S. (2010). The theory of multi-level governance: conceptual, empirical, and normative challenges. Oxford: Oxford University Press.

Pollack, M. A. (2000). The End of Creeping Competence? EU Policy-Making Since Maastricht. JCMS: Journal of Common Market Studies, 38(3), 519-538. doi:10.1111/1468-5965.00233

Saurugger, S. (2008). Interest Groups and Democracy in the European Union. West European Politics, 31(6), 1274-1291. doi:10.1080/01402380802374288 
Schmitter, P. C., \& Streeck, W. (1999). The Organization of Business Interests. Studying the Associative Action of Business in Advanced Industrial Societies. MPIfG discussion paper, 99(1).

Shaffer, G. C., \& Pollack, M. A. (2010). Hard vs. Soft Law: Alternatives. Complements, and Atagonists in International Governance. Minnesota Law Review, 94(3), 706-799.

Sin, C., \& Saunders, M. (2014). Selective acquiescence, creative commitment and strategic conformity: situated national policy responses to Bologna. European Journal of Education, n/a-n/a. doi:10.1111/ejed.12072

Stensaker, B., Harvey, L., Huisman, J., Langfeldt, L., \& Westerheijden, D. F. (2010). The Impact of the European Standards and Guidelines in Agency Evaluations. European Journal of Education, 45(4), 577-587. doi:10.1111/j.1465-3435.2010.01450.x

Voegtle, E. M., Knill, C., \& Dobbins, M. (2011). To what extent does transnational communication drive cross-national policy convergence? The impact of the Bologna process on domestic higher education policies. Higher Education, 61(1), 77-94. doi:10.1007/s10734-010-9326-6

Yagci, Y. (2014). Setting Policy Agenda for the Social Dimension of the Bologna Process. Higher Education Policy, 27(4), 502-528. doi:doi:10.1057/hep.2013.38

Zahariadis, N. (2003). Ambiguity and choice in public policy : political decision making in modern democracies. Washington, D.C: Georgetown University Press. 